\title{
Variation of Stability Constants of Thorium Citrate Complexes with Ionic Strength
}

Article · January 1995

DOI: 10.1524/ract.1996.74.special-issue.123

CITATIONS

22

3 authors, including:

H. N. Erten

Bilkent University

75 PUBLICATIONS 1,047 CITATIONS

SEE PROFILE
READS

59 


\title{
CONF-950946--6 $5 A N D 95-2006 C$
}

\section{VARIATION OF STABILITY CONSTANTS OF THORIUM CITRATE COMPLEXES AND OF THORIUM HYDROLYSIS CONSTANTS WITH IONIC STRENGTH}

\author{
Gregory R. Choppin, Hasan N. Erten*, Yuan-Xian Xia \\ Department of Chemistry, The Florida State University \\ Tallahassee, Florida 32306-3006 USA
}

\begin{abstract}
Citrate is among the organic anions that are expected to be present in the wastes planned for deposition in the Waste Isolation Pilot Plant repository. In this study, a solvent extraction method has been used to measure the stability constants of Thorium(IV)[Th(IV)] with citrate anions in aqueous solutions with (a) $\mathrm{NaClO}_{4}$ and (b) $\mathrm{NaCl}$ as the background electrolytes. The ionic strengths were varied up to $5 \mathrm{~m}(\mathrm{NaCl})$ and $14 \mathrm{~m}\left(\mathrm{NaClO}_{4}\right)$. The data from the $\mathrm{NaClO}_{4}$ solutions at varying $\mathrm{pH}$ values were used to calculate the hydrolysis constants for formation of $\mathrm{Th}(\mathrm{OH})^{3+}$ at the different ionic strengths.
\end{abstract}

Keywords. Thorium / Citrate / Complexation / Hydrolysis / Solvent extraction

\section{INTRODUCTION}

Underground salt beds are being considered by several countries as the site for disposal of nuclear wastes. In order to assess the probability of release of the long-lived actinide elements into the environment from these repositories, it is necessary to model the chemistry of actinides under conditions encountered in brine solutions. For non-vitrified wastes, the interactions of the actinides with organic compounds present from the processing systems may be significant factors in any migration process. In particular, this study is directed to providing stability constant values for Thorium(IV)[Th(IV)] with the residual citrate anion that may be in the nuclear wastes planned for the deposition in the Waste Isolation Pilot Plant repository. Such constants can be used to obtain estimates of the possible effect on the net Th(TV) solubilities. The data were also provided an estimate of $\mathrm{Th}(\mathrm{IV})$ hydrolysis constants in the $\mathrm{NaClO}_{4}$ solutions.

* Present address: Bilkent University, 06533 Bilkent, Ankara, Turkey. 
The use of the titration method to determine such constants requires relatively high metal ion concentrations that may be prevented by hydrolytic precipitation at higher $\mathrm{pH}$ values. In this study, a solvent extraction method [1-5] with radiotracer Th(IV) was used to measure the stability constants with citrate in aqueous solutions with (a) $\mathrm{NaClO}_{4}$ and (b) $\mathrm{NaCl}$ as the background electrolytes. The ionic strengths were varied up to $5 \mathrm{~m}(\mathrm{NaCl})$ and $14 \mathrm{~m}\left(\mathrm{NaClO}_{4}\right)$. Also, the extraction data in the $\mathrm{NaClO}_{4}$ solutions at different $\mathrm{pH}$ values were used to calculate the hydrolysis constants for formation of $\mathrm{Th}(\mathrm{OH})^{3+}$ at the different ionic strengths. The complexation equations are described by the equation:

$$
\mathrm{pM}+\mathrm{qH}+\mathrm{rL}=\mathrm{M}_{\mathrm{p}} \mathrm{H}_{\mathrm{q}} \mathrm{L}_{\mathrm{r}}
$$

with an overall stability constant $B_{\mathrm{pqr}}$ defined as

$$
B_{p q r}=\left[M_{p} H_{q} L_{r}\right] /[M] P[H]^{q}[L]^{r}
$$

This symbolism is suitable if protonated and hydrolysed species are involved as in our system. For hydrolysis, a negative q value is used to refer to the hydroxo species. In the $\mathrm{pcH}(-\log [\mathrm{H}])$ range of 1.5-4.0, the citric acid may form both protonated $\left(\mathrm{ThHCit}^{+2}\right.$ and $\mathrm{ThH}_{2} \mathrm{Cit}^{+3}$ ) and unprotonated $\left(\mathrm{ThCit}^{+}\right)$complexes.

The equations of the concentrations of the citrate anions are as follows:

$$
\begin{aligned}
& {\left[\mathrm{Cit}^{3}\right]=[\mathrm{Cit}]_{\mathrm{T}} /\left(1+\mathrm{K}_{1}[\mathrm{H}]+\mathrm{K}_{1} \mathrm{~K}_{2}[\mathrm{H}]^{2}+\mathrm{K}_{1} \mathrm{~K}_{2} \mathrm{~K}_{3}[\mathrm{H}]^{3}\right)} \\
& {\left[\mathrm{HCir}^{-2}\right]=[\mathrm{Cit}]_{\mathrm{T}} /\left(1+\mathrm{K}_{2}[\mathrm{H}]+\mathrm{K}_{2} \mathrm{~K}_{3}\left[\mathrm{H}^{2}+1 / \mathrm{K}_{1}[\mathrm{H}]\right)\right.} \\
& {\left[\mathrm{H}_{2} \mathrm{Cir}^{-1}\right]=[\mathrm{Cit}]_{\mathrm{T}} /\left(1+\mathrm{K}_{3}[\mathrm{H}]+1 / \mathrm{K}_{2}[\mathrm{H}]+1 / \mathrm{K}_{1} \mathrm{~K}_{2}[\mathrm{H}]^{2}\right.}
\end{aligned}
$$

where: [Cit] $T$ is the total citrate molarity; $K_{1}, K_{2}$ and $K_{3}$ are the first, second and third protonation constants of citric acid, respectively and $[\mathrm{H}]$ is the hydrogen ion molarity.

In the solvent extraction systems, the distribution constant (D) is defined as

$$
\mathrm{D} \equiv \Sigma[\mathrm{M}]_{0} / \Sigma[\mathrm{M}]_{\mathrm{aq}}
$$




\section{DISCLAIMER}

Portions of this document may be illegible in electronic image products. Images are produced from the best available original document. 
Assuming that there is only a single organic(o) phase species, $M A_{n}$, and the presence of various species in the aqueous(aq) phase, eq. 4 can thus be expressed by

$$
D=\left[M A_{n}\right] /\left([M]_{a q}+[M L]_{a q}+[M H L]_{a q}+\left[M_{2}\right]_{a q}+\left[M(H L)_{2}\right]_{a q}+. .\right)
$$

where $\mathrm{L}$ is a complexing anion in the aqueous phase. This equation can be rewritten to include the stability constant of the aqueous complexes [6]:

$D=\left[M A_{n}\right]_{0} /[M]_{a}\left(1+B_{101}+B_{111}[H]+B_{121}[H]^{2}\right)[L]+\left(B_{102}+\beta_{122}[H]^{2}+B_{142}[H]^{4}\right)[L]^{2}$

For the analysis of the extraction data, apparent stability constants are defined as

$$
\begin{aligned}
& B_{1} \equiv B_{101}+B_{111}[\mathrm{H}]+B_{121}[\mathrm{H}]^{2} \\
& B_{2} \equiv B_{102}+B_{122}[H]^{2}+B_{142}[\mathrm{H}]^{4}
\end{aligned}
$$

Using $D_{0}$ for the distribution constant in the absence of complexation allows revision of eq. 6 in terms of the apparent stability constants:

$$
D_{0} / D=1+B_{1}[L]+B_{2}[L]^{2}
$$

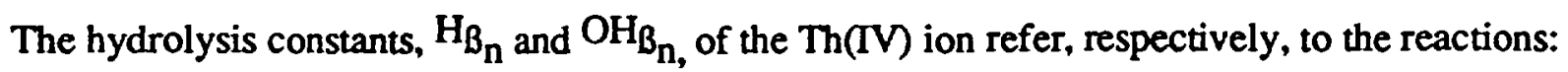

$$
\begin{aligned}
& \mathrm{Th}^{+4}+\mathrm{n} \mathrm{H}_{2} \mathrm{O}=\mathrm{Th}(\mathrm{OH})_{n^{4-n}} \\
& \mathrm{Th}^{+4}+\mathrm{nOH}^{-}=\mathrm{Th}(\mathrm{OH})_{n}^{4-n}
\end{aligned}
$$

The two hydrolysis constants are related by

$$
\log \mathrm{H}_{B_{n}}=\log \mathrm{OH}_{B_{n}}+n \log \mathrm{K}_{\mathbf{w}}
$$

where $\mathrm{K}_{\mathbf{W}}$ is the ionization product of water.

The hydrolysis constant for formation of $\mathrm{Th}(\mathrm{OH})^{3+}$ can be calculated from the equation:

$$
B_{101}(\mathrm{cal})=B_{101}(\exp ) /\left(1+\mathrm{OH}_{\left.B_{1} /\left[\mathrm{H}^{+}\right]\right)}\right.
$$


where $B_{101}$ (cal) and $B_{101}$ (exp) are the calculated and experimental apparent stability constants, respectively.

\section{EXPERIMENT}

\section{Reagents and Solutions}

Stock solutions of $1.0 \times 10^{-3} \mathrm{M}$ and $1.6 \times 10^{-4}$ sodium citrate (Aldrich) were prepared. TTA and DBM were purified by sublimation. Stock solutions of $0.01 \mathrm{M}$ TTA and $0.1 \mathrm{M}$ DBM in toluene (Fischer Chemicals) were prepared and stored in the dark. Sodium perchlorate (anhydrous, Mallinckrodt) and sodium chloride (Fisher Chemicals) were used without further purification.All reagents were analytical grade.

230 Th tracer (obtained from Oak Ridge National Laboratory) was prepared in a solution of $\mathrm{pH} 2\left(\mathrm{HClO}_{4}\right)$ such that $10 \mu \mathrm{l}$ of the solution gives approximately $16000 \mathrm{cpm}$. The ${ }^{230} \mathrm{Th}$ tracer was checked for radioactive purity by alpha and gamma spectrometry.

To minimize sorption of Th(IV) at pH's where hydrolysis occurs, all solutions used in the experiments were filtered with a $0.2 \mu \mathrm{m}$ microfiltration system.

\section{Apparatus and Equipments}

A Packard Instrument Tri-Carb 4000 (Hewlett Packard Instruments) Liquid Scintilation Counter was used to count the radioactivity in Ecolume cocktail (ICN Biomedicals Co.). A GeLi Gamma Spectrometer (Canberra) was used to check the radioactive purity.

An Accumet 950 (Fisher Scientific) pH meter was used with a combination of glass electrodes (Corning Semi-Micro Combination). The $\mathrm{KCl}$ solution in the salt bridge of the electrode was replaced with a saturated $\mathrm{NaCl}$ solution, as the low solubility of $\mathrm{KClO}_{4}$ in high ionic strengths of perchlorate solution causes erratic reading. The electrode was calibrated with $4.00 \pm 0.01$ and $7.00 \pm 0.01 \mathrm{pH}$ buffer standard solutions (Fisher Scientific). The $\mathrm{pH}$ readings were converted to hydrogen concentration $(\mathrm{pcH})$ using eq. 14 which is described in detail in the Results and Discussion section..

A laminar flow hood (Environmental Air Control Inc.) was used to reduce problems of sorption in solution from suspended particles.

A 655 Dosimat (Metrohm) buret was used to conduct the potentiometric titration in a 30 $\mathrm{ml} \mathrm{jacketed} \mathrm{cell} \mathrm{controlled} \mathrm{to} 25.0 \pm 0.1^{\circ} \mathrm{C}$ by water flow from an Isotemp bath.

A water bath (Model 1200-00 Circulator, Cole-Parmer Instrument Company) controlled to $25.0 \pm 0.1^{\circ} \mathrm{C}$ was used for the extraction experiments. 


\section{Experimental Procedure}

\section{Determination of the dissociation constants of citric acid}

The dissociation constants of citric acid, pK values, were determined at different ionic strengths of $\mathrm{NaClO}_{4}$ and $\mathrm{NaCl}$ solutions by potentiometric titration. The titrations were carried out using $10.0 \mathrm{ml}$ solutions in a $30 \mathrm{ml}$ jacketed cell through which water at $25.0 \pm 0.1^{\circ} \mathrm{C}$ was passed. Nitrogen gas was bubbled through the cell solution to remove the dissolved carbon dioxide. A standard solution of $0.03 \mathrm{M} \mathrm{NaOH}$ (in $\mathrm{NaClO}_{4}$ or $\mathrm{NaCl}$ of appropriate ionic strength) was titrated against initial volume, $\mathrm{V}_{0}$, of $\mathrm{NaClO}_{4}$ or $\mathrm{NaCl}$ of the same ionic strength. In order to maintain a small $\mathrm{pH}$ change after each addition of titrant, variable amounts of titrant were used in the additions. A differential graphical technique [7] to analyze the titration data used a plot of $\left(\mathrm{dn} / \mathrm{dln}\left[\mathrm{H}^{+}\right]\right) \times \mathrm{CL}_{\mathrm{L}}$ versus $\mathrm{pcH}$, which allows evaluation of the $\mathrm{pK}_{\mathrm{w}}$ and the acid constants, where $\mathrm{n}$ is the ratio of the concentration of proton bounded to ligand and total concentration of ligand, $\mathrm{CL}$, is the total concentration of ligand.

\section{Extraction Procedure}

For each extraction experiment, $5.00 \mathrm{ml}$ of aqueous solution adjusted to the appropriate $\mathrm{pH}$ were placed in vials, which had been silanized as described elsewhere [3]. Aliquots of citric acid stock solution were added to each vial followed by $5.00 \mathrm{ml}$ of TTA or DBM in toluene. The concentration of the organic extractant was adjusted according to the ionic strength and $\mathrm{pH}$ of the solution so that $D$ fell between 0.1 and 10. After additon of $10 \mu \mathrm{l}$ of $230 \mathrm{Th}$ tracer, the vials were shaken for 2-3 hours at room temperature $\left(25 \pm 0.1^{\circ} \mathrm{C}\right)$. Kinetic studies confurmed that the extraction equilibrium was attained in about 10 minutes. The vials were centrifuged and duplicate aliquots were taken from both phases for scintillation counting and $\mathrm{pH}$ measurement.

\section{RESULTS AND DISCUSSION}

\section{Dissociation Constants of Citric Acid}

The dissociation constants of citric acid in different ionic strengths of $\mathrm{NaClO}_{4}$ and $\mathrm{NaCl}$ (in molality, $\mathrm{m}$ ) solutions are given in Table 1 . The $\mathrm{pK}$ values at low ionic strengths are reported in the literature [8]. Our values are in agreement with these data. The $\mathrm{pH}$ can be converted to $\mathrm{pcH}$ using the following calibration equation: 


$$
\mathrm{pcH}=\mathrm{mpH}+\mathrm{b}
$$

where $m$ and $b$ are constants for a certain ionic strength electrolyte.

The glass electrode calibration coefficient, $\mathrm{b}$ and $\mathrm{K}_{\mathrm{w}}$, in both electrolytes at different ionic strengths can be simultaneously measured with the dissociation constants from the (dn/din[ $\left[\mathrm{H}^{+}\right]$) $\mathrm{CCL}$ plots (Figure 1). The results are listed in Table 1. The values of cirric acid were used in the calculation of free citrate anion.

The $\mathrm{K}_{\mathrm{W}}$ values in different ionic strengths were used to calculate the hydrolysis constants of thorium ion at various ionic strengths of $\mathrm{NaClO}_{4}$.

\section{Thorium Citrate Complexation}

A series of experiments with $\mathrm{pcH}$ ranging from 1.8 to 4.0 were conducted at ionic strengths of $1.0,3.5,6.5,10.0$, and $14.1 \mathrm{~m} \mathrm{NaClO}_{4}$; while for $\mathrm{NaCl}$ solutions, the $\mathrm{pcH}$ was kept at 3.0 for the experiments as the ionic strengths varied. The free concentration of citric anion in each extraction vial was calculated from the measured $\mathrm{pcH}$, the total concentration of citrate, and the $\mathrm{pk}_{\mathrm{a} 1}, \mathrm{pk}_{\mathrm{a} 2}$, and $\mathrm{pk}_{\mathrm{a} 3}$ of citric acid.

Typical curves showing functions of D vs. citrate anion concentration are shown in Figures 2 and 3. A linear curve for $1 / D$ indicates $1: 1$ complexes that provide $B_{1}$ from the slope. If (Do/D-1)/[L] is plotted as the ordinate, a linear regression over the appropriate concentration range of [Cit]f gives the second apparent stability constant $B_{2}$ (eq. 9). From analysis of such curves, the apparent stablility constants, $B_{1}$ and $B_{2}$, were obtained in the different ionic strengths of $\mathrm{NaCl}$ and $\mathrm{NaClO}_{4}$ solutions; Table 2 lists these values from at least two extraction experiments. The relationship between the apparent stability constants and the stability constants, $B_{101}, B_{111}$, $B_{102}, B_{121}$, are given by eqs. 7 and 8 . Using the first two terms of eqs. 7 and 8, respectively, and Quattro Pro for windows program (least square regression and optimizer), the stability constants of various mononuclear thorium-citrate complexes in $\mathrm{NaClO}_{4}$ solutions were determined. The values of the constants are given Table 3. The results indicate that the complexation of Th(IV) ion with citrate can increase the concentration of Th(IV) in the different ionic strengths of $\mathrm{NaCl}$ and $\mathrm{NaClO}_{4}$ solutions, even at quite low concentrations $\left(2 \times 10^{-7} \mathrm{M}\right)$.

The variation of apparent stability constants of Th(IV)-citrate complexes with $\mathrm{pcH}$ is shown in Figure 4 . The effect of hydrolysis on the data above about pcH can be seen. The first hydrolysis constants of thorium (IV) cation in various $\mathrm{NaClO}_{4}$ media are summarized in Table 4 with the available literature data. The hydrolysis constants obtained in this study using citrate anion 
as competing ions agree with those reported in the literature for ionic strength $1-3 \mathrm{M}$ [9-14], however, no literature values are reported above $3 \mathrm{M}$ ionic strength.

The bonding of thorium ion to inorganic and organic ligands in complexes can be described well by an ionic model. As a result, the number of ligands as well as their geometric arrangement about the thorium cation are determined primarily by electrostatic and steric factors. The extensive hydrolysis of Th(IV) in even relatively acidic solutions $(\mathrm{pH} \leq 3)$ limits complexation studies because most organic ligands with bonding carboxylate groups require $\mathrm{pH}$ values of 3 or higher to have ionization of the ligand. This study shows that organic acids can form complexes that are sufficiently strong that they can compete with hydrolysis and increase the net concentration of Th(IV) in neutral solutions. The data is being analyzed further by the Pitzer formalism [15] for a later report.

\section{ACKNOWLEDGEMENTS}

This work was performed as part of the Waste Isolation Pilot Plant (WIPP) Actinide Source Term Program, supported at Sandia National Laboratories by the United States Department of Energy under Contract DE-AC04-94AL85000, and at Florida State University under contract AH-5590. We acknowledge the many helpful comments from Dr. Craig Novak during this study.

\section{REFERENCES}

1. Khalili, F. I., Choppin, G. R., Rizkalla, E. N. 1988. The Nature of Complexation by Halates and Chloroacetates, Inorg. Chim. Acta Vol. 143, 131-135 .

2. Caceci, M. S., Choppin, G. R. 1983. The Determination of the First Hydrolysis Constant of Eu(III) and Am(III), Radiochim. Acta Vol.33, 101-104.

3. Caceci, M. S., Choppin, G. R. 1983. The First Hydrolysis Constant of Uranium(VI), Radiochim. Acta Vol.33, 207-212.

4. Choppin, G. R., Mathur, J. N. 1991. Hydrolysis of Actinyl(VI) Cations, Radiochim. Acta Vol.52/53, 25-28.

5. Erten, H. N.,Mohammed, A. K., Choppin, G. R. 1994. Variation of Stability Constants of Thorium and Uranium Oxalate Complexes with Ionic Strength, Radiochim. Acta Vol.66/67,123128. 
6. Martell, A. E. and Smith, R. M. 1978. Critical Stability Constants, Plenum Press, New York.

7. Chen, J. F., Xia, Y. X., Choppin, G. R. : Personal Communication.

8. Smith, R. M., Martell, A.E. 1989. Critical Stability Constants, Plenum Press, New York.

9. Chubakova, E. T.,Skorik, N.A. 1973. The Stability of Lanthanum, Yttrium, Scandium, and Thorium Glutarate and Oxalate Complexes in Aqueous and Aqueous Alcoholic Solutions, Russian J. Inorg. Chem., Vol.18,1446-1447.

10. Pan, K., Hseu , T.M. 1955. Physico- Chemical Study on the Hydrolysis of Thorium Nitrate, Bull. Chem. Soc. Japan Vol.28, 162.

11. Kraus, K. A., Holmberg, R. W. 1954. Hydrolytic Behavior of Metal Ions.III. Hydrolysis of Thorium(IV), J. Phys. Chem. Vol58, 325.

12. Baes Jr., C. F., Meyer, N. J., Roberts, C. E. 1965. The Hydrolysis of Thorium(TV) at 0 $95^{\circ} \mathrm{C}$, Inorg. Chem. Vol.4, 518.

13. Hietanen, S., Sillen, L. G. 1968. Studies on the Hydrolysis Metal Ions 60 . Hydrolysis of the Thorium(IV) Ion in $3 \mathrm{M} \mathrm{(Na)Cl}$ Medium, Acta Chimica Scand. Vol.22, 265.

14. Bruno, J., Cassas, I., Grenthe, I., Lagerman, B. 1987. Studies on Metal Carbonate Complexes, 19. Complex Formation in the Th(IV)- $\mathrm{H}_{2} \mathrm{O}-\mathrm{CO}_{2}$ (g) System, Inorg. Chim. Acta Vol.140, 299.

15. Pitzer, K. S., 1991. Activety Coefficients in Electrolyte Solutions, 2 nd Edition, CRC Press, Boca Raton Ann Arbor Boston London.

\section{DISCLAIMER}

This report was prepared as an account of work sponsored by an agency of the United States Government. Neither the United States Government nor any agency thereof, nor any of their employees, makes any warranty, express or implied, or assumes any legal liability or responsibility for the accuracy, completeness, or usefulness of any information, apparatus, product, or process disclosed, or represents that its use would not infringe privately owned rights. Reference herein to any specific commercial product, process, or service by trade name, trademark, manufacturer, or otherwise does not necessarily constitute or imply its endorsement, recommendation, or favoring by the United States Government or any agency thereof. The views and opinions of authors expressed herein do not necessarily state or reflect those of the United States Government or any agency thereof. 


\section{Captions}

Figure 1. Plot of $(\mathrm{dn} / \mathrm{d} \ln [\mathrm{H}]) \times \mathrm{Cl}_{\mathrm{L}}$ vs. $\mathrm{pcH}$ in $5.0 \mathrm{~m} \mathrm{NaCl}$ solution at $25^{\circ} \mathrm{C}$; point is experimental data; solid line is calculated data.

Figure 2. Plot of $1 / \mathrm{D}$ vs. [Citrate]f in $1.0 \mathrm{~m} \mathrm{NaCl}$ solution at pcH 3.0; point is experimental data; solid line is calculated data.

Figure 3. Plot of $\left.\left(D_{0} / D-1\right) / C i t r a t e\right] f$ vs. [Citrate]f in $1.0 \mathrm{~m} \mathrm{NaCl}$ solution at pcH 3.0; point is experimental data; solid line is calculated data.

Figure 4. The first apparent stability constants vs. pcH at $25^{\circ} \mathrm{C}$. 
Table 1. Dissociation Constants of Citric Acid in $\mathrm{NaCl}$ and $\mathrm{NaClO}_{4}$ Solutions at Temprature $=25^{\circ} \mathrm{C}$.

$\begin{array}{cllll}\text { Ionic strength } & \mathrm{pK}_{\mathrm{a} 1} & \mathrm{pK}_{\mathrm{a} 2} & \mathrm{pK}_{\mathrm{a} 3} & \mathrm{~b}^{(\mathrm{a})}\end{array} \quad \mathrm{pK}_{\mathbf{w}}$

\begin{tabular}{rrrrrr}
\hline 0.1 & $2.99 \pm 0.01$ & $4.42 \pm 0.01$ & $5.70 \pm 0.01$ & $0.03 \pm 0.01$ & $13.80 \pm 0.02$ \\
0.3 & $2.72 \pm 0.01$ & $4.19 \pm 0.01$ & $5.41 \pm 0.01$ & $0.11 \pm 0.01$ & $13.75 \pm 0.02$ \\
0.5 & $2.92 \pm 0.02$ & $4.26 \pm 0.01$ & $5.33 \pm 0.02$ & $0.14 \pm 0.01$ & $13.77 \pm 0.01$ \\
1.0 & $2.95 \pm 0.01$ & $4.24 \pm 0.01$ & $5.25 \pm 0.01$ & $0.27 \pm 0.01$ & $13.82 \pm 0.02$ \\
3.5 & $2.96 \pm 0.01$ & $4.29 \pm 0.02$ & $5.22 \pm 0.04$ & $0.70 \pm 0.01$ & $14.18 \pm 0.01$ \\
6.5 & $3.27 \pm 0.01$ & $4.63 \pm 0.01$ & $5.56 \pm 0.01$ & $1.12 \pm 0.01$ & $14.70 \pm 0.03$ \\
10.0 & $3.51 \pm 0.01$ & $4.93 \pm 0.01$ & $5.85 \pm 0.01$ & $1.52 \pm 0.01$ & $15.46 \pm 0.01$ \\
14.1 & $3.73 \pm 0.02$ & $5.25 \pm 0.01$ & $6.31 \pm 0.01$ & $2.05 \pm 0.01$ & $16.29 \pm 0.01$ \\
\hline & & $($ in sodium chloride solutions) & \\
\hline 0.1 & $2.93 \pm 0.01$ & $4.36 \pm 0.01$ & $5.63 \pm 0.01$ & $0.04 \pm 0.01$ & $13.81 \pm 0.01$ \\
0.3 & $2.88 \pm 0.02$ & $4.25 \pm 0.01$ & $5.38 \pm 0.01$ & $0.13 \pm 0.01$ & $13.70 \pm 0.04$ \\
0.5 & $2.90 \pm 0.02$ & $4.23 \pm 0.01$ & $5.27 \pm 0.01$ & $0.17 \pm 0.01$ & $13.72 \pm 0.01$ \\
1.0 & $2.88 \pm 0.05$ & $4.18 \pm 0.01$ & $5.20 \pm 0.02$ & $0.35 \pm 0.01$ & $13.73 \pm 0.02$ \\
2.0 & $2.87 \pm 0.01$ & $4.19 \pm 0.01$ & $5.12 \pm 0.01$ & $0.51 \pm 0.01$ & $13.81 \pm 0.01$ \\
3.0 & $2.98 \pm 0.03$ & $4.28 \pm 0.01$ & $5.17 \pm 0.01$ & $0.70 \pm 0.01$ & $13.96 \pm 0.02$ \\
5.0 & $3.13 \pm 0.02$ & $4.49 \pm 0.01$ & $5.35 \pm 0.01$ & $1.09 \pm 0.01$ & $14.33 \pm 0.01$ \\
\hline
\end{tabular}

(a) Values from eq. 14. 
Table 2. Apparent stability constants of Th(IV)-Citrate Complexes at $25^{\circ} \mathrm{C}$.

pcH

A. Ionic Strength of $\mathrm{NaClO}_{4}(\mathrm{~m})$

1.0

3.5

6.5

10.0

14.1

$\log \beta_{1}$

\begin{tabular}{llllll}
\hline 1.84 & $10.93 \pm .07$ & $10.02 \pm .07$ & $10.69 \pm .02$ & $11.65 . \pm 02$ & $12.68 \pm .04$ \\
\hline 2.37 & $9.90 \pm .03$ & $9.23 \pm .04$ & $9.80 \pm .03$ & $10.62 \pm .04$ & $11.24 \pm .03$ \\
\hline 3.12 & $9.41 \pm .07$ & $8.97 \pm .09$ & $9.46 \pm .10$ & $10.23 \pm .07$ & $10.99 \pm .05$ \\
\hline 3.46 & $9.54 \pm .07$ & $9.13 \pm .06$ & $9.57 \pm .02$ & $9.73 \pm 05$ & $10.57 \pm .07$ \\
\hline 3.98 & $8.74 \pm .11$ & $8.65 \pm .07$ & $8.98 \pm .06$ & $8.84 \pm .08$ & $10.43 \pm .09$ \\
\hline
\end{tabular}

$\log \beta_{2}$

$\begin{array}{llllll}1.84 & 21.27 \pm .19 & 21.16 \pm .09 & 22.09 \pm .05 & 23.04 \pm .01 & 25.16 \pm .08\end{array}$

\begin{tabular}{llllll}
\hline 2.37 & $19.30 \pm .12$ & $19.14 \pm .25$ & $19.87 \pm .11$ & $20.91 \pm .09$ & $22.92 \pm .03$ \\
\hline 3.12 & $19.06 \pm .03$ & $18.31 \pm .13$ & $18.50 \pm .15$ & $20.24 \pm .02$ & $22.15 \pm .02$ \\
\hline 3.46 & $18.27 \pm .04$ & $17.69 \pm .06$ & $19.08 \pm .02$ & $19.85 \pm .03$ & $21.21 \pm .12$ \\
\hline 3.98 & $16.94 \pm .03$ & $16.63 \pm .03$ & $17.78 \pm .08$ & $17.53 \pm .05$ & $19.16 \pm .04$ \\
\hline
\end{tabular}


Table 2 (Cont'd). Apparent Stability Constants of Th(IV) - Citrate Complexes at $25^{\circ} \mathrm{C}$.

\begin{tabular}{|c|c|c|c|c|c|c|}
\hline \multirow[t]{2}{*}{$\overline{\mathbf{p c H}}$} & \multicolumn{6}{|c|}{ B. Ionic Strength of $\mathrm{NaCl}(\mathrm{m})$} \\
\hline & $\mathbf{0 . 1}$ & $\mathbf{0 . 3}$ & 160 & 2.0 & 3.0 & 5,0 \\
\hline \multicolumn{7}{|c|}{$\log \beta_{1}$} \\
\hline 3.00 & $10.08 \pm 0.07$ & $9.67 \pm 0.03$ & $9.56 \pm 0.03$ & $9.31 \pm 0.04$ & $9.55 \pm 0.02$ & $10.18 \pm 0.03$ \\
\hline \multicolumn{7}{|c|}{$\log \beta_{2}$} \\
\hline 3.00 & $19.05 \pm 0.02$ & $18.72 \pm 0.04$ & $18.28 \pm 0.03$ & $17.41 \pm 0.06$ & $17.33 \pm 0.04$ & $19.12 \pm 0.04$ \\
\hline
\end{tabular}


Table 3. Stability Constants of Th(IV) - Citrate Complexes in $\mathrm{NaClO}_{4}$ Solutions at Temperature $=25^{\circ} \mathrm{C}$.

\begin{tabular}{ccccc}
\hline I,m & $\log \mathrm{b} 101$ & $\log \mathrm{b} 111$ & $\log \mathrm{b} 102$ & $\log \mathrm{b} 122$ \\
\hline 1.0 & $9.19 \pm 0.13$ & $12.18 \pm 0.05$ & $18.62 \pm 0.25$ & $23.94 \pm 0.03$ \\
3.5 & $8.91 \pm 0.09$ & $11.32 \pm 0.06$ & $17.83 \pm 0.21$ & $23.86 \pm 0.15$ \\
6.5 & $9.32 \pm 0.11$ & $12.00 \pm 0.08$ & $18.64 \pm 0.29$ & $24.58 \pm 0.04$ \\
10.0 & $9.57 \pm 0.05$ & $12.96 \pm 0.09$ & $19.85 \pm 0.20$ & $25.61 \pm 0.02$ \\
14.1 & $10.59 \pm 0.08$ & $13.51 \pm 0.11$ & $21.61 \pm 0.31$ & $27.64 \pm 0.05$ \\
\hline
\end{tabular}


Table 4. First hydrolysis constants of Th(IV) cation in various $\mathrm{NaClO}_{4}$ media at $25^{\circ} \mathrm{C}$.

\begin{tabular}{cll}
\hline Ionic Strength, $\mathbf{m}$ & $\log \mathbf{H}_{\mathbf{B}_{1}}$ & Reference \\
\hline 0 & -3.20 & 8 \\
$0.01-0.04$ & -3.61 & 10 \\
0.05 & -3.92 & 10 \\
0.10 & -4.00 & 10 \\
0.30 & -4.12 & 10 \\
0.51 & -4.26 & 10 \\
1.04 & $-4.15 \pm 0.04$ & 11 \\
1.04 & $-4.16 \pm 0.05$ & 12 \\
3.51 & $-4.13 \pm 0.06$ & 14 \\
1.04 & $-3.75 \pm 0.02$ & p. w. \\
3.51 & $-3.56 \pm 0.03$ & p. w. \\
6.50 & $-3.99 \pm 0.02$ & p. w. \\
10.02 & $-3.87 \pm 0.07$ & p. w. \\
14.06 & $-4.09 \pm 0.08$ & p. w. \\
\hline
\end{tabular}

p.w.: present work. 


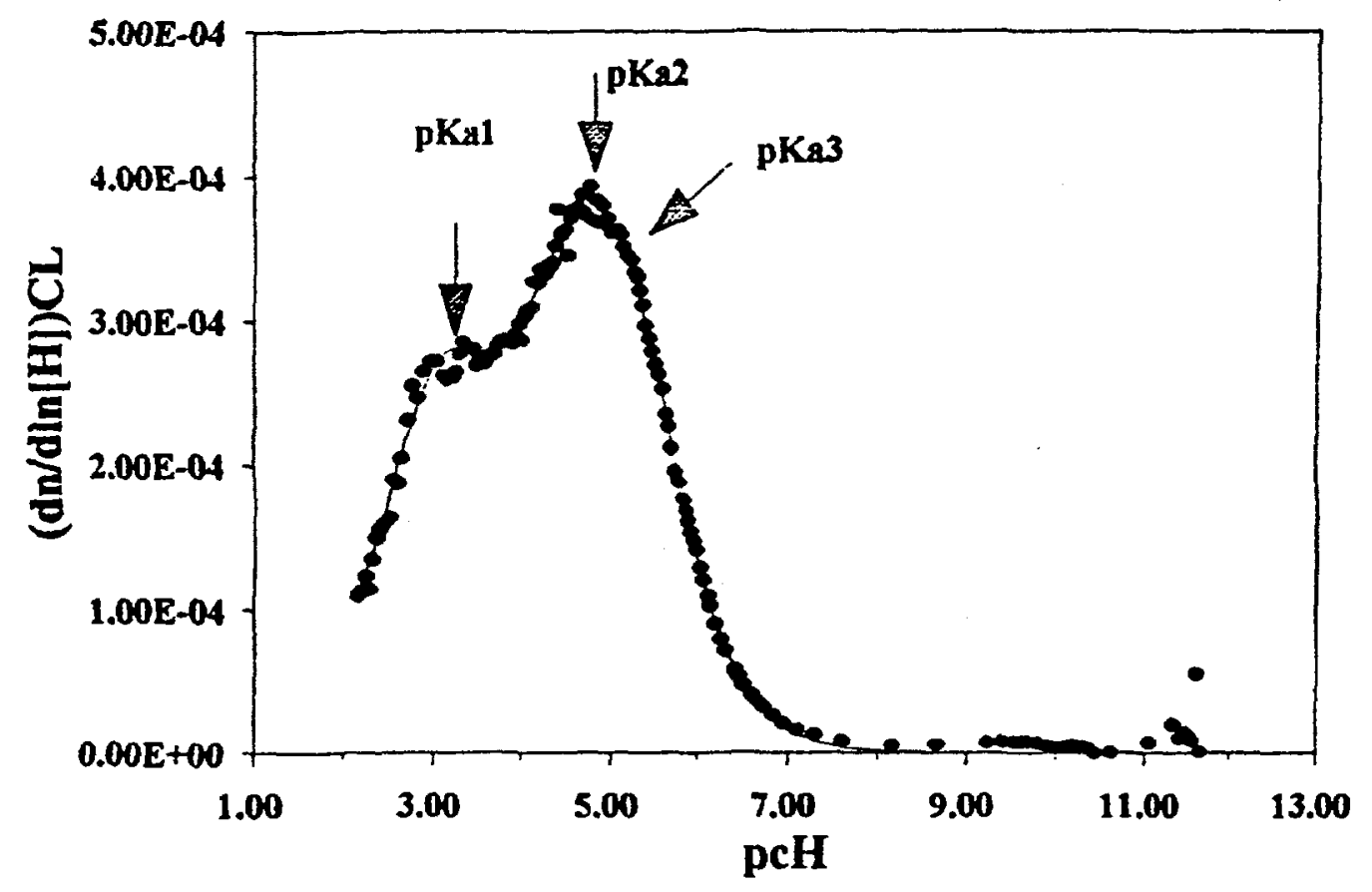




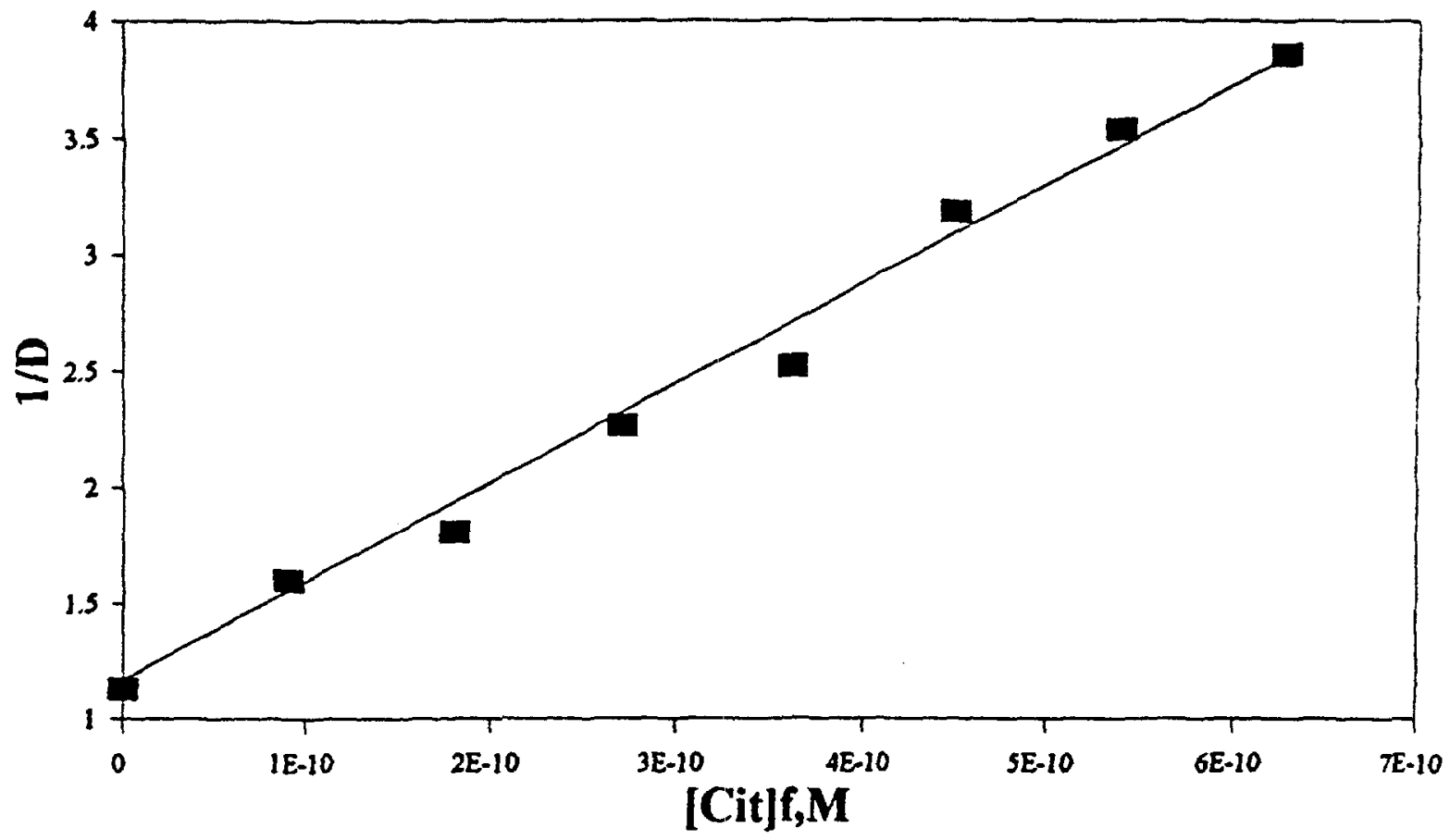




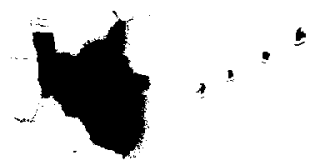

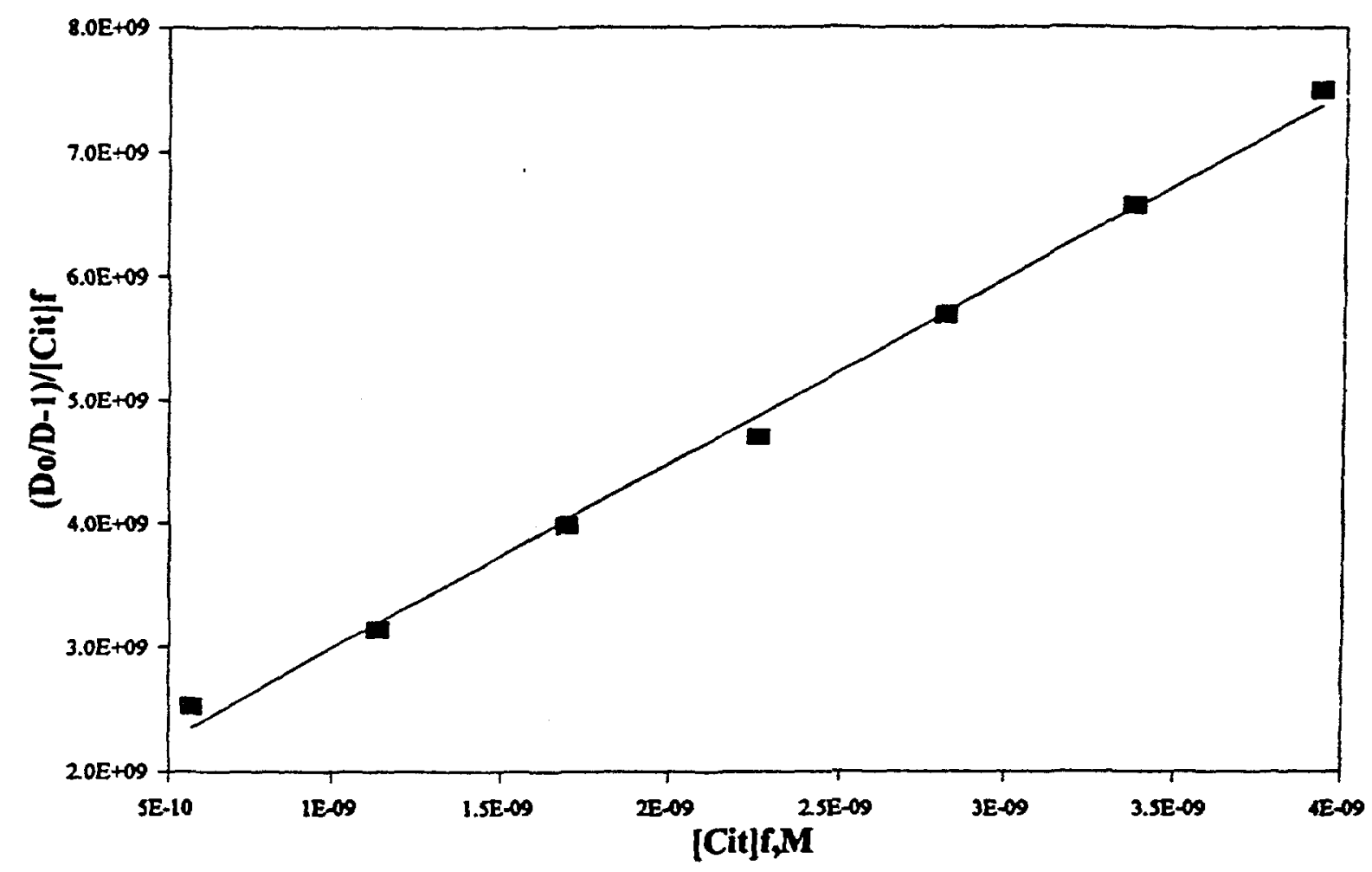




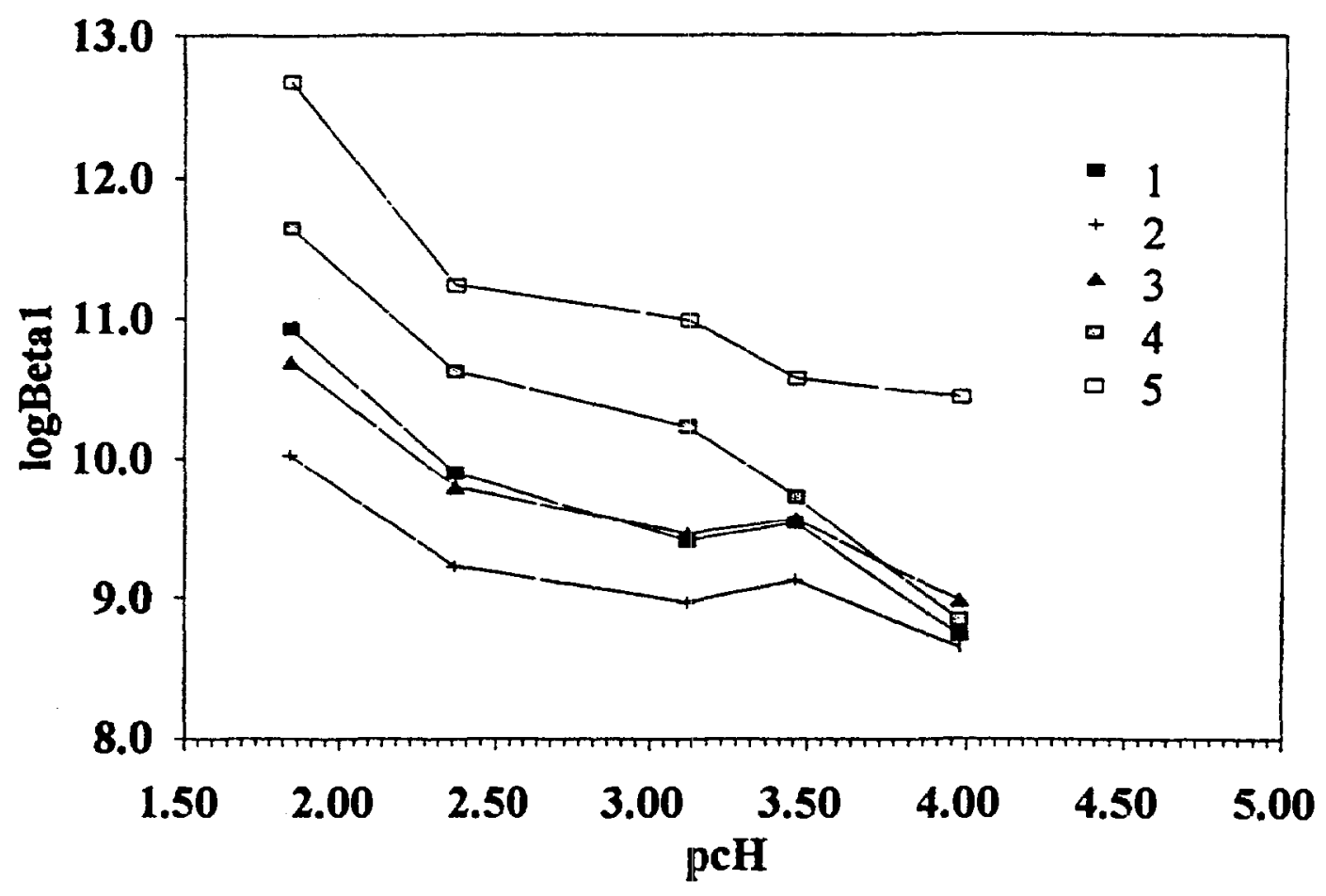

